\title{
TRANSFORMASI MODERNISASI PESANTREN SALAF
}

\author{
Shulhan ${ }^{1}$ \\ ${ }^{1}$ STIT Aqidah Usymuni, , Sumenep \\ ${ }^{1}$ shulhan.live@gmail.com
}

Diterima: 8 Juli 2021 | Disetujui: 17 Juli 2021 | Dipublikasikan : 19 Juli 2021

\begin{abstract}
Abstrak
Pesantren salaf yang semula berfungsi sebagai pusat pembelajaran agama secara tradional mengalami transformasi modernisasi baik sistem maupun kurikulum untuk mengakomodasi tuntutan masyarakat dan perkembangan zaman modern. Tulisan ini dimaksudkan untuk membahas tentang transformasi modernisasi pesantren salaf dengan setting lokasi di Pulau Madura. Metode penelitian yang digunakan adalah pendekatan kualitatif dengan jenis fenomenologi untuk menggambarkan dinamika fenomena modernisasi yang terjadi di tengah pesantren salaf. Teknik pengambilan data berupa observasi dan interview. Observasi dikakuan dengan cara mengamati secara langsung hal-hal yang terjadi di tengah-tengah obyek penelitian. Wawancara dilakukan kepada pihak terkait (stakeholder) untuk memperoleh informasi tentang bagaimana proses transformasi modernisasi pada pesantren salaf. Kehadiran peneliti menjadi intrumen kunci (key instrument) dalam proses pengumpulan data untuk memastikan originalitas data yang diperoleh. Hasil penelitian ini antara lain; Pertama, pesantren salaf-modern yaitu pesantren yang semula salaf tradisional dikembangkan dengan memasukkan sistem sekolah yang diimplementasikan di lembaga pendidikan di bawah Kementerian Pendidikan dan Kebudayaan dan Kementerian Agama dari jenjang terendah hingga pendidikan tinggi. Kedua, pesantren salafinklusif, lembaga pendidikan pesantren tetap mempertahankan tradisi lama dalam mengajarkan kitab-kitab kuning dengan metode tradional klasik dan membolehkan santri untuk mengenyam pendidikan formal di luar pesantren secara proporsional. Ketiga, pesantren kombinasi salaf modern-inklusif, pesantren yang pola sistemnya mengombinasikan salaf-modern dan salaf-inklusif. Keempat, pesantren salaf-renewed learning method, lembaga pendidikan pesantren yang persisten mengajarkan kitab kuning dengan system pembelajaran seperti yang terdapat dalam sekolah formal yang berada di bawah naungan pemerintah.
\end{abstract}

Kata Kunci: Pesantren, salaf, transformasi, modernisasi 


\begin{abstract}
[TRANSFORMASI MODERNISASI PESANTREN SALAF]. Salaf islamic boarding house (pesantren salaf) which in early has function as center of learning and teaching religion traditionally modernizes its self both systems and curriculum to accomadate society need and current issue of modern era. This article is intended to discuss about the transformation of modernization of pesantren salaf which occurs in Madura Island. The author intentionally used the qualitative method and took phenomenological to depict dynemics of transforming modernization around salaf islamic boarding house. The reseacrher here applied observing and interviewing techniques as a way of data collection. The observation was conducted by looking at the research object directly to collect proper dates. The interview was applied to stakeholders for gaining information related to how process transforming of modernization in that institute worked. The researcher himself took an essential role play in reaching appropriate data from qualified sources to guarantee its originality collected during the data collection period. The results were shown as below: firstly, salaf-modern pesantran. It was emerging as traditional learning and focused on teaching yellow book (classic Islamic book) then it was developed by incorporating national educational system like schools under both education and culture ministry affair and religion ministry affair from basic to higher education. Secondly, salaf-inclusive pesantren which consistently nurtures traditional learning system to teach pupils (santries) Islamic knowledge and the santri permissively gets access to take national education outside pesantren management. Thirdly, mixed salaf modern-inclusive pesantren adopting both systems used by salaf-modern and salaf-inclusive. Fourthly, salaf-renewed learning pesantren which persistently teach yellow book by using a classical model.
\end{abstract}

Keywords: Pesantren, Salaf, Transformation Modernization



This work is licensed under a Creative Commons Attribution-NonCommercial 4.0 International License 


\section{PENDAHULUAN}

Pesantren merupakan salah satu sistem pendidikan tertua di negara Inonesia. Lembaga pendidikan pesantren dikatakan sebagai tradisi besar dalam mempelajari ilmu agama oleh umat Islam di negeri ini. Tradisi besar itu berupa pembelajaran agama Islam yang dilakukan oleh masyarakat muslim di pesantren yang berada di tanah Jawa (Van Bruinessen, 1994). Pesantren sebagai salah satu model pendidikan asli (indigenous) negeri ini keberadaannya memberikan dampak signifikan terhadap dinamika khasanah ilmu Islam dan keislamaan bagi pemeluk agama Islam di nusantara. Pembumian Islam di negeri ini salah satunya dilakukan melalui pendidikan pesantren yang bercorak tradisional dan bersinggungan langsung dengan masyarakat.

Mula-mula pendidikan pesantren dicipatakan untuk mewadahi aktivitas pembelajaran tradisional bagi pemuda-pemudi muslim untuk mendalami ilmu-ilmu agama Islam menggunakan literatur klasik yang biasa disebut kitab kuning. Santri-santri mendalami agama dengan cara mengkaji kitab kuning kepada kiai atau ustadz menggunakan system tradisional yaitu mendengarkan kiai membaca lafal - makna kitab dan penjelasan kadungannya. Teknik lain yang digunakan adalah santri membaca kitab (lafal dan makna) di depan kiai sekaligus menjabarkan maksud atau kadungan dari teks yang dibaca. Metode hafalan dan musyawarah juga digunakan dalam kegiatan belajar mengajar di lingkungan pesantren. Pembelajaran yang diimplementasikan di pondok pesantren pada masa ini sangat sederhana tetapi fokus dan konsisten dalam membina mental pritual dan karakter peserta didik secara ikhlas dan dedikatif.

Sistem pendidikan salaf pada pelaksanaannya tidak seragam (heterogen) dan sangat dipengaruhi oleh pola pikir (mindset) dan kecenderungan kiai yang mengasuhnya. Pengasuh pesantren memiliki hak prerogative secara absolut untuk menentukan haluan atau arah pembelajaran di lembaga pendidikan pesantren yang di kelola. Konsentrasi dan minat pribadi seorang kiai menentukan arah kebijakan pengelolaan dan kurikulum yang diterpakan dalam sebuah pesantren. (Falikul Isbah, 2020). Sebagian pesantren menekankan santri untuk menguasai fiqih dan llmu terkait seperti ushul fiqih. Ada juga pesantren yang didirikan secara khusus dikonsentrasikan pada bidang Tafsir Al-Quran dan Hadits. Sebagian lagi pesantren salaf dimaksudkan untuk mengajarkan santri tasawuf dan akhlak. Masing-masing pesantren memiliki ciri khas dan entitas yang berbeda sesuai visi-misi yang dikembangkan oleh pendidirinya.

Rumusan masalah penelitian ini adalah bagaimana dinamika transformasi modernisasi pesantren salaf di Pulau Madura. Riset ini bertujuan untuk mengambarkan dinamika perubahan atau transformasi moderniasai pesantren salaf di atas dalam merespon perkembangan zaman dan kebutuhkan masyarakat. Penelitian ini difokuskan untuk mengkaji art of modernization dari pesantren salaf. Penulisan hasil penelitian ini dimaksudkan untuk memetakan ragam model modernisasi pesantren salaf atau tradisional dalam merespon isu-isu aktual modern.

Beberapa penelitian terdahulu yang mengangkat tema pesantren dan modernisasi. Salah satunya penelitian yang ditulis oleh Asrohah (2011) membahas tentang dinamika pesantren dalam merespon isu-isu modernitas dan mekanisme dalam transformasi organisasi. Penelitian ini mengungkapkan empat hal penting yaitu kemampuan pesantren dalam beradaptasi dengan dunia luar, pencapaian tujuan dalam skala besar, kemampuan untuk menyatukan hal-hal unik dari pesantren sebagai sub budaya dan kemampuan melestarikan tradisi pesantren. Pribadi (2013) menulis jejaring keagamaan di Madura yang meliputi pesantren, Nahdlatul Ulama dan kiai sebagai inti dari budaya santri. Peneliti ini mengungkap peran kiai, organisasi NU dan pesantren sebagai intitusi pendidikan dalam membentuk budaya santri. Pesantren di Madura tetap konsisten menjaga tradisi salaf dan mengembangkan diri sebagai bagian dari modernisasi. Pesantren tidak lagi hanya mengajarkan agama saja tetapi juga menawarkan pelajaran sekuler seperti sejarah dan bahasa asing. Latif (2012) meneliti peran kiai dan pesantren dalam melestarikan tradisi Islam dan upaya negoisasi dengan modernitas. Hasil penelitian ini mengungkap perubahan tujuan pendidikan pesantren yang semula santri dilatih untuk menjadi ahli agama sekarang santri dididik untuk menjadi masyarakat terdidik yang mampu memaski bursa kerja dan perguruan tinggi. Berdasarkan 
kajian pustaka di atas, penelitian ini berfungsi sebagai pelengkap untuk menggambarkan model-model modernisasi pesantren salaf di Madura.

Perkembangan zaman dan transformasi teknologi informasi menuntut segala hal di dunia menyesuikan diri agar bisa survive di tengah perubahan arus kehidupan manusia yang terus berkembang pesat secara dramatis. Pesantren belum mampu menjawab tantangan modernisasi dan globalisasi yang belakarang ini masuk ke negara kita (Hamruni, 2016). Pendapat ini menegaskan bahwa pendidikan pesantren belum mampu merespon isu-isu actual terkini yang berhubungan dengan modernisasi dan arus globalisasi. Akan tetapi komentar di atas untuk era sekarang tidak relevan lagi kerena banyak lembaga pesantren bertansformasi menyesuaikan diri dengan trend kehidupan masyarakat yang terus berkembang.

Zarkasy (2020) dalam temuan risetnya mengemukakan hal berbeda bahwa pendidikan pesantren mengalami proses modernisasi. Dirinya mencontohkan pesantren Gontor sebagai icon pesantren modern yang dipelopori oleh Imam Zarkasy. Program kulliyatul muallimin al-Islamiyah merupakan tahapan pertama proses modernisasi di Pondok Darus Salam itu. Pendepat ini mematahkan pendapat sebelumnya dengan bukti kongkret bahwa pesantren tidak stagnan dan dapat merespon dinamika terbaru. Pondok pesantren Darus Salam Gontor merupakan bukti nyata bahwa pesantren terus berkembang pesat menjawab tantangan terkini secara aktual. Kulliyatul muallimin itu berupakan contoh nyata modernisasi pesantren kerena kegiatan dilaksanakan secara modern menggunakan teknik dan pendekatan pembelajaran yang berkembang di dunia pendidikan.

Pesantren salaf belakangan ini merespon perkembangan zaman dan para kiai yang mengelolanya berusaha mengembangkan pesantren agar tidak ketinggalan zaman. Corak dan model upaya modernisasi tersebut beragam antar satu dengan yang lain. Pesantren merupakan institusi pendidkan Islam yang bersifat tradisonal yang muncul dan tumbuh bersamaan dengan kedatangan Islam di tanah Jawa. (Solichin, 2019). Pesantren salaf merupakan institusi pendidkan tradisional yang lahir dan berkembang seiring munculunya Agama Islam di pulau Jawa.
Pendirian pesantren untuk mendidik dan membina masyarakat agar memahami dan mendalami ajaran Islam sejak zaman Islam sebagai agama baru sehingga menjadi agama dengan jumlah penganut terbanyak seperti sekarang ini.

Pesantren salaf adalah pesantren yang dikhususkan untuk menyediakan pelayanan pembelajaran menggunakan buku-buku Islam klasik yang sering disebut kitab kuning sebagai inti pendidikan, (Hamruni, 2016). Pesantren salaf difokuskan pada pembelajaran dan pembinaan masyarakat Islam tentang ilmu-ilmu keislaman dan keruhanian. Lembaga pendidikan berbasis pesantren dimaksudkan untuk menjadi wahana yang dapat menumbuhkan dan meningkatkan pemahaman masyarakat dalam mendalami ilmu agama Islam dengan cara-cara tradisonal. Buku yang digunakan yaitu kitab-kitab kalsik yang berbahasa Arab tanpa harkat. Kurikulum pesantren ditentukan oleh pengasuh (pendiri pesantren atau generasi penerusnya) secara otomon tidak berafiliasi kepada kementerian terkait.

Eksistensi pesantren berdampak positif dalam pembangunan moral bangsa Indonesia (Hidayat, 2016). System pendidikan yang berbasis dormitory (asrama) efektif dalam membentuk karakter dan moral serta habituating process (pembiasaan) dalam menjalankan ajaran agama Islam secara berkesinambungan dan terus menerus. Belakang pesantren dengan transformasi yang terus dikembangkan mampu melahirkan output (lulusan) yang menguasai ilmu agama dan ilmu umun yang berbasis applied (terapan) dan teknologi sekaligus. Pesantren pada awalnya mengembangkan bidang keilmuan melalui interaksi antara pemuda muslim Indonesia dengan ilmuwan dari Timur Tengah (Khojir, 2016). Dewasa ini pesantren mengembankan jejaring internasional dengan negara-negara maju di benua Eropa dan Amerika untuk meningkatkan kualitas pembelajaran di lingkugan lembaga pendidikan yang berada di bawah naungan pesantren. Tujuannya adalah untuk melahirkan lulusan yang dapat memberikan dampak besar terhadap pembangunan peradaban bangsa.

Modernisasi pesantren dimulai dari proses adopsi sistem pendidikan madrasah dan mengajarkan mata pelajaran non agama. Salah satu pesantren yang mengalami proses ini 
adalah pesantren yang didirikan oleh $\mathrm{KH}$. Hasyim Asy'ari dimana lembaga ini hingga dipimpin oleh $\mathrm{KH}$ Wahid Hasyim ditekankan untuk menjadi pesantren yang menerapkan sistem modern (Azra, 2013: 223). Transformasi modernisasi merupakan upaya yang dilakukan oleh pesantren salaf untuk merespon tantangan umat yang terus berkembang. Usaha itu dilakukan untuk membekali para santri agar mampu berkiprah di tengah-tengah masyarakat modern. Moderniasasi ini menyentuh ranah kurikulum yang umumnya mengalami penyempitan orientasi yang dikhususkan pada bidangbidang agama saja seperti fiqih, nahwu-sarraf, aqidah (Hidayah, 2019). Heriyudanta (2016) mengatakan bahwa pesantren tradisional tidak bisa menghindari pengaruh modernisasi, utamanya perkembangan era yang diikuti oleh progresifitas ilmu pengetahuan (science) dan teknologi. Pesantren tersebut menghadapi tantangan-tantangan (challenges) yang muncul sebagai produk kehidupan modern. Kemampuan pesantren merespon tantangan itu dapat menjadi indikator dalam mengikuti arus modernisasi.

\section{METODE PENELITIAN}

Penelitian ini menggunakan metode penlitian kualitiatif untuk mengeksplorasi fenomena-fenomena yang berkembang dalam pesantren salaf dalam konteks modernisasi. Penelitian kualitatif digunakan untuk menelaah kejadian-kejadian menggunakan pendekatan tertentu (Creswell, 2014) Populasi atau sampel penelitian ini ditentukan secara purposif dimana memungkinkan peneliti untuk menentukan sasaran penelitian berdasarkan pertimbangan-pertimbangan tertentu yang dapat dipertanggungjawabkan secara ilmiah. Dalam sampel purposuf, peneliti secara sengaja menentukan sasaran dan subyek penelitian untuk dikaji dan dipelajari untuk mendalami fenomena terkait yang terjadi (Creswell, 2009). Dalam penelitian ini, peneliti menentukan pesantren yang terdapat di Pulau Madura sebagai sasaran penelitian. Pulau Madura dipilih sebagai lokasi penelitian karena banyaknya lembaga pesantren yang berkembang dari masa ke masa. Pesantrenpesantren di Pulau Madura pada mulanya bersifat tradisional-salaf yang kegiatan pembelajarannya tidak formal dan di luar sistem pendidikan pemerintah. Selain itu, moyoritas masyarakat Madura sangat tinggi animonya untuk memondokkan putra-putrinya ke lembaga pesantren apalagi belakangan pesantren mampu mengubah wujud menjadi lembaga pendidikan modern yang tidak kalah dengan pendidikan non pesantren.

Subyek Penelitian disini adalah pesantren salaf yang di Pulau Madura seperti Pesantren An-Nuqoyah, Al-Amien Prenduan, Pesantren Darul Istiqomah Batuan, Pesantren Raudhatul Thalibin Kolor Sumenep, Pesantren Mambaul Ulum Bata-Bata Pemekasan, pesantren AlIs'af Kallaban dan Pesantren Darul Ulum Banyuanyar. Jumlah santri di beberapa pesantren di atas bervariasi, ada yang mencapai ribuan, ratusan dan puluhan. Jumlah santri di Al-Amien, Mambaul Ulum BataBata, Darul Ulum Banyuanyar dan AnNuqoyah mencapai ribuan santri dari berbagai daerah bahkan dari luar Madura dan ada pula dari luar negeri. jumlah santri di PP Darul Istiqomah dibawah seratus dan di pesantren Al-Is'af dan Raudhatut Thalibin di atas seratus orang. Sedangkan obyek penelitian dalam riset ini ialah dinamika transformosi moderniasi yang terjadi pada lembaga pesantren tersebut.

Teknik wawancara dan observasi secara sengaja dipilih sebagai instrumen pengumpulan data dalam proses penelitian ini. Peneliti berfungsi sebagai instrument kunci dalam pengumpulan data sehingga peneliti dituntut untuk terjun langsung ke lapangan untuk memperoleh data dari sumber utama dan untuk memastikan auntentitas dan keaslian data (Sugiyono, 2014). Kehadiran peneliti ke lokasi penelitian mutlak diperlukan agar dapat berinteraksi langsung dengan nature yang diteliti sehingga menapatkan informasiinformasi penting yang mendukung data penelitian. Dengan terjun langsung ke lokasi penelitian, peneliti dapat menggunakan seluruh indera dan emosinya untuk menangkap informasi dari subyek penelitian.

Adapun teknik analisis ada yang digunakan disini mengadopsi formulasi enam tahapan. Pertama, melakukan coding dan transkirpsi data. Kedua, peneliti aktif mengumpulkan data sekaligus menganislisnya secara bersamaan (simultan). Ketiga, melakukan pembacaaan data secara berulangulang untuk mengoreksi dan mengevaluasi keabsahan data. Keempat, peneliti manganalis 
data temuan secara intensif. Kelima, menelaah data menggunakan berbagai perspektif. Keenam, proses konklusi (Creswell, 2014). Teknik analisis data di atas digunakan untuk memperoleh data-data yang valid dan dapat dipertanggungjawabkan sehingga memudahkan peneliti untuk mencapai tahapan kesimpulan.

\section{TEMUAN DAN PEMBAHASAN}

\section{Temuan}

Pesantren salaf yang berada di Madura seperti Pesantren Al-Amien, Pesantren Mambaul Ulum Bata-Bata, Pesantren Darul Ulum Banyuanyar, Pesantren Al-Is'af, Pesantren Darul Istiqomah, Pesantren Raudhatut Thalibin dan Pesantren AnNuqoyah dalam merespon tantangan perkembangan zaman berupaya melakukan modernisasi dalam beberapa hal antara lain:

2. Salaf-Modern, pesantren ini mengadopsi system pendidikan nasional ke dalam pendidikan pesantren. Sistem dan kurikulum pendidikan yang diselengarakan Pemerintah diimpor ke dalam lingkungan pesantren dan diterapkan secara seimbang bersamasama kurikulum pesantren yang telah lebih dahulu diberlakukan yang sifatnya lokal dan otonom. Kurikulum pesantren dan kurikulum pendidikan nasional digunakana secara bersama-sama di dalam pesantren. Sekolah atau madrasah formal disediakan di di dalam lingkungan pesantren untuk mendidik santri ilmuilmu agama dan ilmu umum secara formal dan setelah lulus peserta didik memperoleh ijazah yang diakui pemerintah. Madrasah diniyah diselenggarakan untuk mendidik para santri mendalami ilmu-ilmu agama secara khusus.

Tabel 1. Karakteristik Pesantren Salaf Modern

\begin{tabular}{|c|l|}
\hline $\begin{array}{c}\text { Transformasi } \\
\text { Modernisasi }\end{array}$ & \multicolumn{1}{c|}{ Karakteristik } \\
\hline \multirow{5}{*}{ Salaf-Modern } & $\begin{array}{l}\text { Memasukkan kurikulum } \\
\text { pendidikan nasional ke } \\
\text { dalam pesantren }\end{array}$ \\
\cline { 2 - 2 } & $\begin{array}{l}\text { Integrasi kurikulum } \\
\text { pesantren dan kurikulum } \\
\text { pendidikan nasional }\end{array}$ \\
\cline { 2 - 2 } & Sekolah/Madrasah formal \\
\hline
\end{tabular}

\begin{tabular}{|l|l|}
\hline & (MI/SD, MTs/SMP, \\
MA/SMA dan bahkan \\
Pedidikan Tinggi) \\
diselenggarakan di dalam \\
lingkungan pondok \\
\cline { 2 - 3 } & Madrasah Diniyah \\
diselenggarakan khusus \\
untuk mendidik santri \\
mendalami ilmu agama
\end{tabular}

3. Salaf-inkulsif, sistem pembelajaran konsisten bersifat tradisional dan tetap fokus pada kajian kitab kuning serta memberi kesempatan kepada santri mengikuti pendidikan nasional di luar pesantren. Santri-santri yang berkeinginan menembuh pendidikan nasional dapat bersekolah di luar pesantren di luar jamjam kegiatan pesantren yang bersifat wajib dan mengikat bagi semua santri.

Tabel 1. Karakteristik Pesantren Salaf Inklusif

\begin{tabular}{|l|l|}
\hline $\begin{array}{l}\text { Transformasi } \\
\text { Modernisasi }\end{array}$ & \multicolumn{1}{c|}{ Karakteristik } \\
\hline \multirow{5}{*}{ Salaf-Inklusif } & $\begin{array}{l}\text { Menggunakan kurikum } \\
\text { tradional pesantren tanpa } \\
\text { memasukkan kurikulum } \\
\text { nasional }\end{array}$ \\
\cline { 2 - 2 } & $\begin{array}{l}\text { Santri dibolehkan } \\
\text { mengikuti pendidikan } \\
\text { fomal di luar pesantren }\end{array}$ \\
\cline { 2 - 2 } & $\begin{array}{l}\text { Santri keluar masuk } \\
\text { lingkungan pondok secara } \\
\text { terbuka pada jam-jam } \\
\text { tertentu terutama pada jam } \\
\text { sekolah }\end{array}$ \\
\hline
\end{tabular}

4. Kombinasi salaf-modern inklusif, memadukan kedua system pembaruan/modernisasi pesantren di atas. Pesantren ini menyediakan dua pilihan bagi santri. Siswa yang diterima di sekolah negeri (terutama sekolah favorit) dapat memilih pondok ini untuk mengasah dan meningkatkan wawasan agama Islam dan proses pembentukan moral. Pesantren juga menyedian pendidikan nasional bagi santri yang tidak ingin repot keluar masuk pondok untuk bersekolah. 
Tabel 1. Karakteristik Pesantren Salaf Kombinasi (Modern-Inklusif)

\begin{tabular}{|c|c|}
\hline $\begin{array}{l}\text { Transformasi } \\
\text { Modernisasi }\end{array}$ & Karakteristik \\
\hline \multirow{4}{*}{$\begin{array}{l}\text { Kombinasi Salaf } \\
\text { Modern - Salaf } \\
\text { Inklusif }\end{array}$} & $\begin{array}{l}\text { Memasukkan kurikulum } \\
\text { pendidikan nasional ke } \\
\text { dalam pesantren dalam } \\
\text { bentuk MTs dan MA } \\
\text { secara terintegrasi dengan } \\
\text { sistem pesantren }\end{array}$ \\
\hline & $\begin{array}{l}\text { Santri dapat memilih } \\
\text { mengikuti pendidikan } \\
\text { formal di dalam pesantren } \\
\text { atau di luar pesantren }\end{array}$ \\
\hline & $\begin{array}{l}\text { Santri yang bersekolah di } \\
\text { luar dapat keluar masuk } \\
\text { lingkungan pondok secara } \\
\text { terbuka pada jam-jam } \\
\text { tertentu yaitu pada jam } \\
\text { sekolah }\end{array}$ \\
\hline & $\begin{array}{l}\text { Madrasah Diniyah } \\
\text { diselenggarakan untuk } \\
\text { pendalaman penguasaan } \\
\text { ilmu agama }\end{array}$ \\
\hline
\end{tabular}

5. Salaf-renewed learning method, pesantren salaf yang persisten dengan tradisi pembelajaran kitab kuning secara ekslusif tetapi dalam bentuk sistem kelas. Pembelajarn berbentuk kelas-kelas dan berjenjang tetapi tetap fokus pada bidang agama saja.

Tabel 1. Karakteristik Pesantren Salaf Renewed learning method

\begin{tabular}{|c|l|}
\hline $\begin{array}{c}\text { Transformasi } \\
\text { Modernisasi }\end{array}$ & \multicolumn{1}{c|}{ Karakteristik } \\
\hline \multirow{5}{*}{ Salaf- renewed } & $\begin{array}{l}\text { Mengajarkan kitab-kitab } \\
\text { kuning secara intensif }\end{array}$ \\
\cline { 2 - 2 } learning method & $\begin{array}{l}\text { Pembelajaran berbentuk } \\
\text { kelas dan berjenjang }\end{array}$ \\
\cline { 2 - 2 } & $\begin{array}{l}\text { Kegitan pendidikan } \\
\text { bersifat mandiri tidak } \\
\text { berafiliasi kepada } \\
\text { kementerian yang } \\
\text { membidangi pendidikan }\end{array}$ \\
\hline
\end{tabular}

\section{Pembahasan}

Pesantren salaf yang semula dikonsentrasikan untuk mendidik santri untuk mendalami ilmu agama dengan system pembelajaran tradisional diusahakan untuk mampu menjawab perkembangan zaman. Munculnya temuan ilmu terapan dan teknologi dan ilmu-ilmu modern lainnya menuntut setiap individu untuk menyesuaikan diri dengan lingkungan dan kebiasaan baru. Hal itu menuntut manusia untuk senantiasa meningkatkan kemampuan dan skill agar tidak ketinggalan. Jika tidak mampu meningkatkan kamampuan, keterampilan dan kapasitas diri, manusia akan tergilas oleh system kehidupan yang serba terbarukan.

Pada mulanya, masyarakat dari kalangan santri dianggap cukup hanya berbekal pendidikan pesantren tradisional untuk terjuan di tengah masyarakat. Kaum santri mampu eksis berkontribusi dalam pembangunan nasioanal dengan berbekal pendidikan tradisional tanpa ijazah. Mereka berkiprah sebagai guru, ustadz, kiai kampung, pengusaha bahkan politisi. Namun zaman terus berkembang dan kebutuhan serta lifestyle meningkat seiring terbukanya informasi tanpa batas ruang dan waktu sebagai konskuensi pemanfaatan teknologi. Hal itu cenderung menjadi pemicu bagi menusia agar meningakatkan kapasitasnya supaya bisa bertahan hidup dan menyesuaikan diri dengan kebiasaan baru.

Kondisi ini dianggap sebagai tantangan (challenge) bagi kalangan pesantren dan dirasa perlu direspon dengan pembaruan system pembelajaran di lingkungannya. Pesantren yang semula hanya menggunakan pendekatan tradisional yang dibangun atas kekuatan moral, dibenahi dan dikembangkan agar mampu memberikan pelayanan pendidikan yang prima dan dapat membekali santri untuk berkiprah dalam membangun nasional. System pesantren mengadopsi system pendidikan nasional dan diterapkan sebagai bagian dari system pendidikan yang berlaku di lingkungan pesantren.

Materi pembelejaran tidak hanya berkutat pada hal-hal kitab kuning kuning tetapi juga memasukkan mata pelajaran yang ditetapkan oleh pemerintah. Lulusan pesantren kemudian mendapatkan ijazah yang diakui dalam system pendidikan nasional (sisdiknas) sehingga bisa melanjutkan ke jenjang yang lebih tinggi berikutnya. Pesantren tidak mengisolasi diri secara tertutup dan menerima hal-hal baru yang dipandang dapat mendatangkan kemasalahatan bagi umat. Salah satu faktor yang menjadikan pesantren mampu survive adalah kemampuannya untuk menerima perubahan-perubahan baru tanpa harus menghilangkan prinsip dan nilai dasar yang telah dibangun (Azra, 2005).

Pembelajaran agama dan tradisi keislaman 
yang dikembangkan di pesantren diajarkan menggunakan system sekolah tidak lagi menggunakan cara-cara tradisional. Ilmu agama dan ilmu pengetahuan umum samasama diajarkan secara seimbang dalam satu institusi pendidikan pesanten ini. Hal ini sebagai wujud nyata untuk menjawab tantangan pendidikan sekuler yang dihadapi oleh masyarakat Islam dan terisoloasinya pendidikan islam tradisional (Munadi, 2016).

Banyak pesantren modern di pulau Madura mencoba untuk mengombinasikan sistem pendidikan sekuler dan pendidikan Islam (Pribadi, 2013). Tradisi lama berupa pengajaran agama Islam dijaga dengan baik agar penguasaan terhadap teori-teori dan aplikasi ilmu-ilmu keislaman terjaga dalam dari setiap umat muslim. Pembelajaran ilmuilmu modern sebagai basis pengembangan peradaban manusia juga diadopsi untuk menyiapkan insan pesantren dalam menghadapi tantangan kehidupan yang terus berkembang.

Kearifan dan tradisi dalam dunia pesantren dipegang dan dijaga secara erat bahkan dijadikan capital yang digunakan untuk meningkatkan kualitas hidup masyarakat dengan berkesinambungan (Hadi, 2016). Eksistensi pesantren tersebut berfungsi sebagai inkubasi pendidikan untuk menyiapkan kaderkader masyarakat yang dapat membawa perubahan (agent of change) ke arah yang lebih baik dan membawa manfaat untuk lingkungan. Alumni pesantren berkontribusi dalam berbagai bidang kehidupan strategis sesuai keahilan dan passion masing-masing. Santri-santri setelah keluar dari lembaga pesantren mengalami diaspora yang menyebar dalam berbagai profesi baik di tingkat regional, nasional maupun mancanegara.

Banyak pengelola pesantren salaf menempuh cara modernisasi dengan cara memasukkan system pendidikan nasional ini ke dalam managemen pesantren. Salah satu contohnya adalah pesantren An-Nuqoyah, Sumenep dan pesantren Darul Ulum Banyuanyar, Pamekasan. Kedua pesantren ini bertransformasi dari pesantren salaf tradiosional murni menjadi salaf-modern. Keduanya sama-sama mempertahan nilai-nila pesantren salaf yang berbentuk pengkajian Islam dan tradisi keislaman dalam bentuk pelatihan (riyadhah) dan pembiasaan. Pembelajaran Agama Islam dalam dimensi kognitif dilaksanakan dalam bentuk kelas sebagaimana pendidikan nasional. Pesantren ini menyelenggarakan pendidikan dari tingkat sekolah dasar hingga tingkat pendidikan tinggi.

Penguatan komunitas kaum santri dan pendidikan di lingkungan pesantren senantiasa menjadi poros utama dalam proses peningkatan kualitas pendidikan di kalangan komunitas santri seperti yang terjadi di pesantren An-Nuqoyah (Gaffar Karim, 2009). Pesantren ini menyelenggarakan pendidikan agama dan pendidikan modern yang berafiliasi kepada Kemenetian Pendidikan dan Kementerian Agama. Interaksi antara sesama santri dan kiai dapat membantu setiap santri membentuk jati diri dan kapasitas diri sehingga lahir generasi-generasi yang berkualitas setelah keluar dari pesantren.

Penggunaan kurikulum terintegrasi antara kurikulum asli pesantren dan kurikulum pendidikan nasional diharapkan mampu mencetak lulusan yang menguasai ilmu pengetahuan dan teknologi yang didasari moral atau akhlak yang terpuji (Mas'ud, et al, 2019). Teknologi informasi dan ilmu terapan dewasa ini sangat penting dikuasai oleh para santri karena kehidupan manusia tidak terlepas dari kedua hal tersebut. Sains terapan dan tenologi saat ini menjadi pijakan umat manusia dan mengembangkan segala hal di dunia. Jika santri tidak ikut serta menguasai kedua hal tersebut, pesantren dan masyarakatnya akan terisolalasi dari modernisasi yang tidak dapat dihindari lagi.

Lulusan pesantren dituntut untuk tidak sekedar pandai membaca kitab kuning, bermoral yang baik, dan taat beribadah kepada Allah SWT tetapi mereka harus mendalami ilmu-ilmu terapan seperti farmasi, kedokteran, ekonomi, keuangan, teknik mesin, teknologi pertanian. Hal ini dimaksudkan agar mereka mampu mengambil peran dalam pembangunan nasional. Santri-santri sekarang hendaknya mampu bertransformasi menjadi agen-agen muslim yang mempu mesuk ke sector-sektor penting negara. Tujuannya adalah untuk menjaga keutuhan negara tercinta dari penjajahan berbasis ilmu pengetahuan dan teknologi.

Komitmen santri dalam menjaga keutuhan negara kesatuan negara ini tidak diragukan lagi tetapi itu perlu diterjemahkan ke dalam langkah-langkah yang lebih kongkret, 
sistematis dan terukur. Langkah mengintegrasikan kurikulum nasional ke dalam pendidikan pesantren dimaksudkan untuk membentuk santri agar mampu mampu menguasai ilmu agama dan ilmu pengetahuan sekaligus. Profil lulusan pesantren yang diharapakan adalah tenaga ahli dan intelektual modern yang islami.

Tipe modernisasi pendidikan salaf yang kedua adalah dengan cara memberikan kesempatan kepada santri-santrinya mengikuti pendidikan nasional di luar lingkungan pesantern dan diluar managemen pesantren. Lembaga pesantren ini tetap dalam tradisi lama yaitu mengajarkan ilmu-ilmu agama dengan menggunakan kitab kuning secara tradisional. Inti pembelajaran pesantren ini masih berkutat dalam kitab-kitab klasik dan metode pembelajarannya tidak berupa kelas. Para santri mengikuti kegiatan pondok dari sore hari hingga jam setelah melaksanakan shubuh sebelum berangkat berskolah.

Pola ini biasa ditempuh oleh lembaga pendidikan pesantren yang jumlah santrinya tidak terlalu banyak. Hal ini memungkinkan untuk memantau keluar masuknya santri dengan efektif karena system pesantren ini terbuka dan longgar. Santri tidak dikekang di dalam lingkungan pesantren tetapi meraka biasa kelular masuk pesantren pada jam-jam tertentu. Mereka bisa berinteraksi dengan masyarakat luar pesantren terutama ketika jam-jam sekolah. Kebijakan ini menuntut kesadaran tinggi dari setiap santri untuk selalu menjaga sikap dan nama baik almamater. Pesantren dengan jumlah santri banyak akan kesulitan menarapkan cara ini karena pengurus pesantren akan kewalahan dalam menerbitkan dan memantau mobilitas santri.

Salah satu pesantren yang memberlakukan cara ini adalah Pesantren Darul Istiqomah Batuan, Sumenep. Pesantren memberikan kesempatan bagi santri baik putra maupun putri untuk mengikuti pendidikan nasional di luar karena di dalam tidak disediakan pendidikan nasional. Beberapa santri tiap hari keluar masuk pesantren untuk mengikuti pendidikan nasional setingkat SMP, SMA bahkan perguruan tinggi untuk santri putra. Santri putri hanya dibolehkan bersekolah di luar hingga jenjang SMA sederajat. Kebijakan ini tidak berhubungan dengan bias gender tetapi karena pertimbangan proteksi dan keamanan karena bagi pengasuh pondok ini prempuan rawan bepergian sendiri dan managemen pesantren belum memiliki system perlindungan yang memadai untuk santri putri. Jika santri putri memiliki tekat melanjutkan pendidikan pada jenjang perguruan tinggi dapat mencari pesantren lain yang lebih representatif dan lebih akomodatif terhadap hajat dan minatnya.

Pesantren ini tetap menggunakan metode dan sistem pembelajaran tradisional meskipun lembaga pendidikan modern menawarkan perubahan-perubahan yang sesuai dengan pekembagnan zaman. Pesantren ini tetap mempertahanan kesalafanannya secara murni. Pesantren salaf seperti diketahui bersama hanya mengajarkan ilmu agama saja dengan metode halafan, sorogan dan musyawarah (Zuhri, 2011). Pesantren Darul Istiqomah tetap menggunakan pengajaran-pengajaran tradisional seperti yang dikemukakan oleh Zuhri ini. Sistem belajar dengan cara menghafal, sorogan, dan musayawah dilaksanakan dengan rutin di institui pendidikan ini meskipun secara geografis lembaga ini terletak di pinggiran kota berbeda dengan kebanyakan pesantren yang berada di lokasi yang jauh dari perkotaan.

Pembelajaran yang dilaksanakan di pesantren ini berbasis pada keaktifan peserta didik (learner centered). Masing-masing santri bertanggung jawab atas kesuksesan hasil belajarnya di pesantren yang pertanggungjawabannya secara individual bukan secara kolektif berbasis kelas. Setiap hari dilakukan evaluasi progress hasil belajar masing-masing santri dengan cara diberikan kesempatan untuk melaporkan hasil belajarnya. Asatidz (dewan guru) mendengarkan santri-santri membaca bagian kitab yang telah dipelajari. Selesai membaca kitab kuning dengan teknik lafal-makna perkata berdasarkan kaidah nahwu-sharraf, santri menjabarkan kandungan atau maksud isi kitab tersebut. Ustadz memperhatikan setoran setiap santri dan mengajukan pertanyaan kritis untuk mengetahui sejauh mana santri tersebut memahami maksud kitab yang dibaca. Jika santri berhasil menjawab pertanyaanpertanyaan gurunya, materi bisa dilanjutkan ke bagian selanjutnya. Jika tidak, santri harus mengulang hingga mampu mencerna maksud yang terkandung dalam kitab yang disetorkan itu secara utuh dan komprehensip.

Model ini pada dasarnya merupakan 
aplikasi dari higher order thinking skill (HOTS). Hakikat HOTS merupakan kemampuan untuk berfikir dan mengaplikasikan apa-apa yang telah dipelajari (Aji \& Suparno, 2021). Titik tekan penggunakan pola ini adalah terletak pada keaktifan pelajar untuk mengelaborasi kemampuan berfikir secara mendalam. Santri tidak pasif menerima pembelajaran tatapi dituntut untuk aktif menggali potensi dirinya. Belajar kitab tidak hanya dilakukan dengan mendengarkan gurunya membaca kitab lafalmakna dan menjelaskan isinya tetapi harus berinisiatif sendiri untuk belajar secara sungguh-sunguh hingga mendapat pemahaman. Hasil belajar tersebut dikoreksi di hadapan gurunya sebagai bentuk pertanggungjawaban sekaligus validasi dan pelurusan hal-hal yang kurang tepat. Hal ini sudah dilakukan oleh Imam Syafi'i ketika berguru kepada Imam Malik.

Mereka dihadapkan pada persoalan berupa kesusahan untuk memahami teks berbahasa Arab gundul dan pertanyaan-pertanyaan guru yang tidak dapat diprediksi diluar kebiasaan (extra ordinary). Disini mereka mengasah diri dan mengaktifkan pikirannya untuk menganalisis, mengevaluasi dan berkreasi (Takiddin et al., 2020). Jika santri terbiasa belajar dengan HOTS ini, mental juangnya terpupuk dan terbentuk sehingga tahan banting dalam menghadapi persoalan hidup dan mampu mencari penyelesaannya.

Teknik ini dilakukan untuk semua santri tanpa pengecualian. Semua santri memiliki tanggung jawab yang sama tanpa diskriminasi dan marginalisasi baik santri yang menempuh pendidikan berbasis sekolah nasional maupun santri yang secara intensif mendalami ilmu agama saja. Hal ini diberlakukan di pesantren salaf-inklusif seperti di Pondok Pesantren Assadad dan Pensantren Tengginah Ambunten, Sumenep. Santri-siswa memilki tanggung jawab ganda, sebagai santri berkawajiban untuk memenuhi segala tanggungjawabnya tanpa dispensasi. Sebagai siswa sekolah nasional, tugas dan tanggung jawabnya juga tidak boleh terabaikan. Mereka dituntut untuk bisa mengatur waktu sebaik baik agar kedua pendidikannya tidak terbengkalai.

Modernisasi pesantren selanjutnya dengan cara mengombinasikan salaf-modern dan salaf-inklusif seperti yang dilakukan di pesantren Raudhatut Thalibin Kolor, Sumenep. Pesantren ini di satu sisi menerapkan sistem salaf modern dan di sisi lain juga memberikan peluang kepada siswa sekolah umum (sekolah di luar pesantren) untuk nyantri. Hal ini untuk menfasilitasi dan menjawab kebutuhan masyarakat dalam memenuhi pendidikan putra putrinya. Pesantren ini lokasinya berada di tengah Kota Sumenep sehingga dapat dijadikan alternatif bagi orang tua yang putra-putrinya diterima di sekolah negeri seperti MAN Sumenep dan SMAN 1 Sumenep untuk memondokkan anakanaknya. Memondokkan anak yang sedang menempuh pendidikan sekolah negeri dipandang lebih baik dari pada tinggal di rumah kos atau rumah kontrakan karena selain keamaan lingkungan juga mereka di pondok mendapatkan pembinaan keagamaan dan moral secara intensif.

Dalam konteks ini, pesantren berfungsi seperti halnya salaf-inklusive tetapi yang membedakan adalah kegiatan di pesantren tidak seketat di pesantren yang menerapkan salaf-inklusif murni. Pembelajaran kitab tidak murni student centered tetapi berbentuk program diniyah yang berbasis kelas. Tradisi belajar kitab turats juga terjaga dengan baik dalam bentuk pembelajaran modern dalam berntuk kelas-kelas diniyah. Santri tidak dituntut untuk melakukan setoran belajar mandiri dan menjelaskan isi kitab yang dipelajari di depan guru secara bergiliran satu persatu-satu.

Selain itu, pesantren ini menyediakan pendidikan nasional hingga jenjang Aliyah sederejat bagi masyarakat yang hendak mondok dan bersekolah sekaligus di dalam lingkungan pondok. Masyarakat dari seluruh wilayah pedesaan khususnya dapat memilih untuk memodokkan anak-anaknya disini. Dalam hal ini, pesantren ini menerapkan sistem salaf-modern seperti halnya pesantren An-Nuqoyah dan Al-Amien, Prenduan, Sumenep. Santri di pesantren ini terdapat dua klasifikasi, pertama, santri yang menatap terus menerus di lingkungan pesantren. Setiap hari mereka beraktivitas di dalam pesantren termasuk mengikuti kegiatan pendidikan formal tingkat sekolah menengah pertama dan sekolah menengah atas.

Kedua, santri yang mengikuti pendidikan pesantren paruh waktu. Mereka tiap hari keluar masuk lingkungan pondok kerena 
mengikuti pendidikan formal di luar pondok. Setiap pagi hingga siang atau bahkan sore hari mereka berada di sekolah masing-masing seperti Madrasah Aliyah Negeri Sumenep, Sekolah Menengah Atas Negeri 1 Sumenep. Setelah itu mereka kembali ke pondok mengikuti kegiatan pesantren seperti program madrasah diniyah dan lain-lain hingga istirahat malam di pondok. Besok paginya, mereka menjalankan kegiatan pesantren hingga menjelang berangkat sekolah formal.

Perkembagan pesantren salaf ini merupakan praktik aktual dari integrasi ilmu agama dan ilmu pengetahuan (science). Memadukan ilmu agama dan ilmu pengetahuan dalam proses pembelajaran lebih efektif dalam melahirkan generasi mendatang yang mampu berdaya saing secara global (Abdullah, 2014). Pesantren senantiasa mengembangkan dan memodernisasi sistem pembelajarannya untuk melahirkan output atau lulusan yang siap menghadapi tantangan setelah keluar dari pesantren. Santri-santri yang mengenyam pendidikan di pesantren diproyeksikan menjadi kader-kader muslim yang cakap ilmu agama dan ilmu pengetahuan serta terampil dalam menggunakan teknologi informasi. Pesantren senantiasa berupaya untuk memberikan ruang aktulialisasi baik dalam bentuk pendidkan nasional maupun internasional untuk mengasah keterampilan dan minat santri (Alfinnas, 2018).

Pesantren mengembangkan kegiatan pendidikan dalam bentuk pusat-pusat pengembangan seperti pusat pengembangan bahasa asing, pusat pengembangan jurnalistik dan literasi dan pusat pengembangan sains. Pusat kegiatan ini dimaksudkan untuk mewadani minat santri sesuai passion masingmasing. Pesantren berusaha menghadirkan program-program kegiatan yang dibutuhkan oleh peserta didik. Santri-santri dapat memilih kegiatan-kegiatan sesuai keinginannya tanpa adanya pemaksaan kerana kegiatan ini bersifat pilihan (elective cource) bukan program wajid. Sedangkan program wajib dimasukkan dalam kurikulum yang mengintegrasikan muatan pelajaran pesantren dan pelajaran sekolah.

Model modernisasi pesantren salaf yang terakhir dilakukan dalam bentuk mengadopsi sistem pembealajaran yang berbentuk kelas untuk materi-materi atau kajian kitab kuning. Pesantren ini bertahan mengajarkan ilmu agama Islam kepada para santri tetapi dalam sistem pembelajarn yang tidak tradional lagi. Santri diklasifikasi berdasarkan kemampuannya dan mendapatkan pembelajaran kitab kuning secara berjenjang. Pesantren yang menempuh cara ini salah satunya pesanten Al-Is'af Kallabaan, Sumenep. Sistem kelas diperlakukan di lembaga ini seperti kitab al-fiyah ibn Malik diajarkan dalam empat kelas. Forum diksusi dan belajar kelompok juga diselenggarakn disini.

Pesantren ini tidak mengadopsi kurikulum nasional dan penyelenggarakan pendidikan bersifat otonom sehingga lulusannya tidak mendapatkan ijazah yang diakui negara. Pada dasarnya pesantren ini menggunakan prinsip salaf tradisional dari sisi muatan materi tetapi pembelajarannya dikemas secara modern. Tujuannya adalah untuk memberikan pelayanan maksimal kepada santri dalam mendalami ilmu agama dengan fokus dan konsentrasi tinggi. Santri-santri secara totalitas mendalami ilmu agama baik dari sisi fiqih, tauhid dan kesusantraan bahasa Arab. Pendidikan nasional tidak tersedia dalam pesantren ini dan santri tidak diberi kesempatan untuk mengikuti pendidikan nasional di luar.

Pesantren ini memiliki kecenderungan untuk memprioritaskan kajian-kajian wahyu yang bersifat doktriner dengan penekanan pada mengembangan nalar bayani dan irfani (Hilmy, 2016:129). Kajian yang berhubungan dengan dimensi nalar burhani yang berbasis eksperimen dan inquiri tidak dijadikan kajian prioritas bahkan dikesampingkan. Pengelola pesantren ini menempatkan kajian agama Islam dalam arti sempit yaitu dalam ruang lingkup kitab kuning sebagai instrumen esensial yang perlu didalami. Tema-tema kajian keislaman seperti ekomomi, pengembagan karir, fisika dan kimia dianggap tidak penting dan bukan bagian dari hal yang fundamental.

Pola penyesuaian pesantren salaf dalam merespon isu-isu sosial kemasyarakat terkini sangat erat hubungannya dengan cara pandang dan orientasi kiai yang mengasuh. Transformasi pesantren salaf dalam menyikapi tantangan modern tidak lepas dari peran sentral pengasuhnya. Hal itu yang menyebabkan cara dan model adaptasi pesantren antar satu dengan yang lain bervariasi. Perubahan-perubahan pesantren 
salaf di atas sangat dipengaruhi oleh pemikiran pengasuhnya karena kebijakan pesantren bersifat otonom murni ditentukan oleh pemimpin tertinggi dalam masing-masing pesantren.

Secara umum model-model modernisasi pesantren salaf dimaksudkan untuk meningkatkan kualitas pembelajaran dan pengembangan komunitas santri dan warga sekitar. Pesantren-pesantren yang ada di Indonesia khususnya secara moral dituntut untuk dapat memberikan pelayanan sosial bagi kaum santri dan warga sekitar pesantren (Budiwiranto, 2009). Keberadaan pesantren berfungsi sebagai agent of change, mengubah cara berfikir, bertindak dalam konteks agama dan sosial kemasyarakatan. Pesantren membantu masyarakat untuk meningkatkan kualitas hidup dari sisi keimanan dan prilaku sosial. Kegiatan-kegiatan yang dilaksanakan di pesantren berfungsi sebagai contoh bagi masyarakat sekitar yang kemudian mereka terdorong untuk menirunya dengan tujuan untuk meraih kenaikan kualitas hidup menuju yang lebih baik.

Pesantren tidak sekedar sebagai institusi pendidikan Islam tradisional tetapi juga sebagai lembaga sosio-kultural (Latif Fauzi, 2012). Institusi pesanten memiliki peran penting dalam mengontrol (agent of control) dinamika kehidupan masyarakat. Sosok kiai yang kharismatik di tengah pesantren dijadikan cerminan dan rujukan masyarakat dalam menyikapi dan menyelesaikan persoalan. Hal-hal baru tidak serta merta diterima tetapi diseleksi dengan ketat oleh lembaga pesantren dengan memperhatikan aspek moral, aspek kemanfaatan dan budaya. Perkembagan pola hidup dan budaya di tengah masyarakat muslim dicermati dan dikaji oleh dunia pesanten menggunakan kacamata agama, budaya dan sosial.

Pesantren tidak hanya berfungsi sebagai pengembangan kajian Islam dan pembentukan nilai-nilai Islam tetapi juga identik sebagai lembaga yang senantiasa menjaga tradisi asli Indonesia (Asrohah, 2011). Kaum santri dididik untuk memadukan tradisi-tradisi asli Indonesia dangan syariat Islam dalam kehidupan sehari-hari. Prilaku masyarakat yang sudah ada sebelum Islam tumbuh dan berkembang di tanah air tetap dilestarikan sebaik mungkin. Hal ini sering mendapatkan tanggapan nekatif dari umat muslim di luar komunitas santri. Bagi mereka melestarikan budaya-budaya pra Islam termasuk bid'ah, khurafat dan tahayul padahal kaum santri tidak serta merta melestarikan budaya tesebut begitu saja.

Kalangan pesantren melestarikan tradisi asli bangsa ini dengan cara mengeleminasi nilai-nilai yang bertentangan dengan syariat Islam. Salah satunya tradisi nyekar misalnya. Kaum santri sampai saat ini melaksanakan kebiasaan lama ini tetapi tidak meyakini kekuatan roh leluhur dan semacamnya. Mereka melekukan ziarah kubur bukan seperti yang dilakukan oleh orang-orang sebelum Islam masuk ke Indonesia yang meyakini ajaran animisme dan dinamisme. Mereka murni menjalakan anjuran Nabi untuk melaksankan ziarah kubur dengan tujuan untuk mengikat kematian dan mendoakan orang yang sudah meninggal. Orang-orang yang berziarah ke buburan diharapkan dapat meningkatkan keimanan kepada Allah SWT dan kesadarannya terbentuk bahwa dirinya akan menghadapi kematian. Hal ini secara tidak langsung meningkatkan kesadaran untuk selalu berbuat baik secara ikhlas karena Allah dan meningkatkan kualitas iman.

Pesanten salaf murni yang belum mengadopsi pendidikan formal diorientasikan untuk membangun nilai ketuhanan dan kemanusiaan secara murni. Lembaga ini tidak mendidikan santri untuk mengejar hal-hal keduniaan. Afriani (2013) mengatakan bahwa pendidikan salaf itu dimaksudkan untuk membentuk manusia agar memiliki tiga sifat dasar. Perama, memanusiakan manusia dalam arti kebenaran ditegakkan dengan memperhatikan aspek dasar nilai kemanusian tenpa membeda-bedakan baik dari sisi agama, suku, dan strata sosial. Kedua, kesadaran untuk menekakkan kebenaran dan menjauhi kemungkaran. Kemungkaran di muka bumi ditekan sedemikian rupa sebagai wujud amar ma'ruf nahi mungkar. Ketiga, mengembangkan keimanan yang sempurna kepada Allah.

\section{PENUTUP}

\section{Simpulan}

Pesantren salaf di Madura seperti Pesantren Al-Amien, Pesantren Mambaul Ulum Bata-Bata, Pesantren Darul Ulum Banyuanyar, Pesantren Al-Is'af, Pesantren 
Darul Istiqomah dan Pesantren Raudhatut Thalibin mengalami transformasi moderniasi dalam empat pola, yaitu: Pertama, pesantren memasukkan kurikulum nasional ke dalam sistem pembelajaran pondok sehingga terwujud praktik pengajaran agama dan ilmu pengetahun dalam bentuk kelas secara seimbang. Kedua, pesantren konsisten dalam tradisi pembelanjaran tradional untuk mengkaji kitab-kitab kuning dan memberikan kesempatan kepada santri untuk menimba pendidikan nasional di luar pesantren. Ketiga, pesanten mengombinasikan sistem pertama dan kedua. Keempat, pesantren tetap pesisten secara ekslusif mengkaji kitab turats dengan sistem kelas seperti layaknya sekolah modern hannya saja materi kajiannya tetap bidang agama dan kitab kuning serta tidak diterapkan pendidikan nasional kenegearaan.

\section{Rekomendasi}

Rekomendasi disusun berdasarkan temuan penelitian yang telah dibahas. Rekomendasi dapat mengacu pada tindakan praktis, pengembangan teori baru, dan/atau penelitian lanjutan.

Berdasarkan hasil penelitin ini, peneliti memberikan rekomendasi sebgai berikut.

1. Para peneliti hendaknya mengembangkan penelitian lanjutan tentang kontribusi pesantren yang mengalami proses modernisasi dalam pengembangan peradaban masyarakat muslim di Madura khususnya dan Indonesia secara umum.

2. Pengelola pesantren salaf-inklusif membuat kerjasama khusus dengan sekolah negeri di sekitarnya untuk menjamin keamanan santri yang berskolah di luar agar terhindar dari hal-hal yang tidak diinginkan selama di luar lingkungan pesantren. Salah satu bentuk kerjasama yang dapat dibangun adalah sistem antar-jemput dari sekolah untuk santri-santri yang berskolah di luar tesebut.

3. Pengelola pesantren salaf-modern hendaknya mengembangkan lebih memaksimalkan kualitas pembelajaran ilmu skuler seperti IPA dan Matematika menghasilkan lulusan yang berkiprah dalam bidangbidang prioritas negara. 


\section{DAFTAR PUSTAKA}

Aji, S. H., \& Suparno. (2021). Increasing HOTS of High School Students Using Mobile Technology and Scaffolding Approach: Study on Physics Learning. JTP - Jurnal Teknologi Pendidikan, 22(3), 182-199. Diambil kembali dari : https://doi.org/10.21009/jtp.v22i3.17845

Alfinnas, S. (2018). Membangun Academic Self-Concept Mahasantri Pesantren Nawesea. Education and Human Development Journal, 3(2), 191-198. https://doi.org/10.33086/ehdj.v3i2.59

Amin Abdullah, M. (2014). Religion, science and culture: An integrated, interconnected paradigm of science. Al-Jami'ah, 52(1), 175-203. https://doi.org/10.14421/ajis.2014.521.175-203

Asrohah, Hanu. (2011). The Dynamics Of The Dynamics Of Pesantren Responses Responsestoward Modernity and Mechani toward Modernity and Mechani toward Modernity and Mechanism in Organizing Transformation. Journal of Indonesian Islam. 5(1). 66-90

Azyumardi Azra, D. A. (2005). Revised edition Paper presented Workshop on. Workshop on Madrasa, Modernity and Islamic Education, 1-31.

Azra, Azyumarid. (2013). Pesantren And Madrasah: Modernization Of Indonesian Muslim Society. dalam Begawan Pemacu Ilmu Pengetahun. Jakarta: AIPI

Creswell, J. W. (2009). Reserch Desgne Qualitative, Quantitative and Mixed Method Approaches. London: Sage

Creswell, J. W. (2014). Educational Research: Planning, Conducting and Evaluating Quantitative and Qualitative Research. England: Pearson

Falikul Isbah, M. (2020). Pesantren in the changing indonesian context: History and current developments. Qudus International Journal of Islamic Studies, 8(1), 65-106. https://doi.org/10.21043/QIJIS.V8I1.5629

Gaffar Karim, Abdul.(2009) The Pesantren-Based Ruling Elite In Sumenep In The Post-New Order Indonesia. Journal Of Indonesian Islam, 29-58. DOI: 10.15642/JIIS.2009.3.1.97-121

Hadi, S. (2016). Education Hybridization of Pesantren and its Challenges in Rural Industrialization. 5(December), 261-285.

Hamruni, H. (2016). The Challenge and The Prospect of Pesantren in Historical Review. Jurnal Pendidikan Islam, 5(2), 413. https://doi.org/10.14421/jpi.2016.52.413-429

Heriyudanta, Muhammad. (2016). Modernisasi Pendidikan Pesantren Perspektif Azyumardi Azra. Mudarrisa, Jurnal Kajian Pendidikan Islam, 8(1). 145-172 DOI: 10.18326/mudarrisa.v8i1.145-172

Hidayah, Nur. (2019). Modernisasi Sistem Pendidikan Pesantren Salafiyah. Ri"Ayah.4(1). 60-72

Hidayat, N. (2016). The Implementation of Character Education Model at Islamic Boarding School of Pabelan, Magelang , Central Java. 5(December).

Hilmy, Masdar. (2016). Pendidikan Islam dan Tradisi Ilmiah. Malang: Madani

Khojir (2016). The Pesantren Network in Samarinda. 5(December), 213-233.

Latif Fauzi, Muhammad. (2012), Traditional Islam in Javanese Society The Roles of Kyai and Pesantren in Preserving Islamic Tradition and Negotiating Modernity. Journal of Indonesian Islam. 6(1). 126-144

Mas'ud et al. (2019). Evolution and Orientation of Islamic Education in Indonesia and Malaysia. Journal of Indonesian Islam. 13(1). 21-49. DOI: 10.15642/JIIS.2019.13.1.21-49

Munadi, M. (2016). Integration of Islam and Science : Study of Two Science Pesantrens ( Trensain) in Jombang and Sragen. 5(December). 
Pribadi, Yanwar. (2013). Religious Networks In Madura Pesantren, Nahdlatul Ulama and Kiai as the Core of Santri Culture. Al-Jami‘ah, 51 (1). 1-32. DOI: 10.14421/ajis.2013.511.1-32

Solichin, M. M. (2019). Pesantren Resistance to Modern Education System and It's Implication to Culture of Learning: a Study on Pondok Pesantren Al-Is'af Kalabaan, Guluk-Guluk, Sumenep, Jawa Timur. Addin, 13(1), 85. Diambil kembali dari : https://doi.org/10.21043/addin.v13i1.5664

Sugiyono. (2014). Metode Penelitian Kombinasi, Bandung: Alfabeta

Takiddin, T., Jalal, F., \& Neolaka, A. (2020). Improving Higher Order Thinking Skills through Project-based Learning in Primary Schools. TARBIYA: Journal of Education in Muslim Society, 7(1), 16-28. Diambil kembali dari : https://doi.org/10.15408/tjems.v7i1.14052

Van Bruinessen, M. (1994). Pesantren and Kitab Kuning : Maintenance and Continuation. 121-146.

Wulan Afriani, Dinda. (2013). Budaya Profetik Di Pesantren Salaf. Ibda' Jurnal Kebudayaan Islam. 11(2). 227237

Zarkasyi, H. F. (2020). Imam Zarkasyi ' S Modernization of Pesantren in Indonesia. Qudus International Journal of Islamic Studies (QIJIS), 8(1), 161-200. Diambil kembali dari DOI : 10.21043/qijis.v8i1.5760

Zuhri. M Syaifuddien. (2011). Budaya Pesantren Dan Pendidikan Karakter Pada Pondok Pesantren Salaf. Walisongo, 19(2). 287-309. 